\title{
Prevalence of partial anomalous pulmonary venous connection in adult patients undergoing cardiac magnetic resonance for evaluation of atrial septal defect
}

Venkateshwar Polsani, Faisal Nabi, Dipan J Shah

From 16th Annual SCMR Scientific Sessions

San Francisco, CA, USA. 31 January - 3 February 2013

\section{Background}

The association of partial anomalous pulmonary venous connection (PAPVC) with atrial septal defect (ASD) is known, but its prevalence in adult patients with ASD is not well reported in literature. CMR is recognized as excellent method for shunt quantification and assessment of ASD morphology.

\section{Methods}

A total of 53 consecutive patients who were referred for evaluation of ASD by CMR from 2009-2011 were enrolled in the study. The patients with ASD in the setting of complex congenital heart disease were excluded. All patients were being considered for either percutaneous or surgical closure of ASD. The CMR protocol has been described previously and included standard SSFP (steady state free precision) cines to define the LV morphology and function, phase contrast was used to calculate the shunt fraction and define the ASD morphology, and a high resolution contrast enhanced 3-D MR angiograms were performed to assess pulmonary venous anatomy.

\section{Results}

The total number of patients with ASD was 53. The baseline characteristics and pertinent CMR findings are shown in table 1 . There were $45(85 \%)$ patients with secundum ASD, 6 (11\%) with primum ASD and 2 (4\%) with sinus venosous ASD.

The prevalence of PAPVC in this population $(n=53)$ was $6(11 \%)$. The results of which are shown in the

\footnotetext{
Cardiology, DeBakey Heart and Vascular center, The Methodist Hospital,
} Houston, TX, USA

(c) 2013 Polsani et al; licensee BioMed Central Ltd. This is an Open Access article distributed under the terms of the Creative Commons Attribution License (http://creativecommons.org/licenses/by/2.0), which permits unrestricted use, distribution, and reproduction in any medium, provided the original work is properly cited. table 2. The PAPVC group included four patients with right superior pulmonary vein draining into the superior venacava, one right superior pulmonary vein draining into the right atrium and one left superior pulmonary vein draining into the left innominate vein.

\section{Conclusions}

The prevalence of PAPVC in adult congenital ASD patients referred for further evaluation of ASD is $14 \%$. The incidence was higher in women (15\%) compared to men (10\%).

Since the presence of PAPVC will change the clinical decision of closure of ASD from percutaneous to surgical, the comprehensive CMR assessment for ASD can serve as an excellent non-invasive imaging modality not

Table 1 Baseline demographics and the CMR findings

\begin{tabular}{cc}
\hline Patients(n) & 55 \\
\hline Mean age & $50.9 \pm 18.6$ \\
\hline gender & 34 \\
\hline Hypertension & $18(33 \%)$ \\
\hline Hyperlipidemia & $13(23 \%)$ \\
\hline Diabetes mellitus & $9(16 \%)$ \\
\hline ASD types & $2(3.7 \%)$ \\
\hline Sinus Venosous & $6(11.3 \%)$ \\
\hline Primum & $45(84.9 \%)$ \\
\hline Secundum & $63.5 \pm 9.4$ \\
\hline Mean LV ejection fraction & $53 \pm 10$ \\
\hline Mean RV ejection fraction & $1.9 \pm 0.8$ \\
\hline Mean Qp: Qs
\end{tabular}


Table 2 PREVALENCE OF PAPVC

\begin{tabular}{cc}
\hline ASD type & PAPVC \\
\hline Total $9 n=55)$ & $8(14 \%)$ \\
\hline Sinus Venosous $(n=2)$ & 1 \\
\hline Primum $(n=6)$ & 1 \\
\hline Secundum $(n=45)$ & 4 \\
\hline
\end{tabular}

only to define the morphology and quantify shunt severity of ASD but also to identify the presence of PAPVC.

\section{Funding}

None.

Published: 30 January 2013

doi:10.1186/1532-429X-15-S1-P285

Cite this article as: Polsani et al:: Prevalence of partial anomalous

pulmonary venous connection in adult patients undergoing cardiac

magnetic resonance for evaluation of atrial septal defect. Journal of

Cardiovascular Magnetic Resonance 2013 15(Suppl 1):P285.

Submit your next manuscript to BioMed Central and take full advantage of:

- Convenient online submission

- Thorough peer review

- No space constraints or color figure charges

- Immediate publication on acceptance

- Inclusion in PubMed, CAS, Scopus and Google Scholar

- Research which is freely available for redistribution

Submit your manuscript at www.biomedcentral.com/submit 